\title{
A Challenging Study to Identify Target Proteins by a Proteomics Approach and Their Validation by Raising Polyclonal Antibody
}

\author{
Dawoon Jeong, Beom-Young Park ${ }^{1}$, Jin-Hyoung Kim ${ }^{1}$, and In-Ho Hwang* \\ Department of Animal Science and Institute of Rare Earth for Biological Application, \\ Chonbuk National University, Jeonju 561-756, Korea \\ ${ }^{1}$ Quality Control and Utilization of Animal Products Division, National Institute of Animal Science, RDA, \\ Suwon 441-350, Korea
}

\begin{abstract}
This study was conducted to validate the theoretical feasibility of a technique to identify biomarkers in Korean native black pig (KNP) and a commercial Landrace breed. Using two-dimensional electrophoresis, we found six proteins (NADH dehydrogenase Fe-S protein 1, an unnamed protein product, similar to T-complex protein 1, annexin $\mathrm{V}=\mathrm{CaBP} 33$ isoform, fatty acid-binding protein, and catechol $O$-methyltransferase), which appeared in KNP alone. We raised polyclonal antibodies (used as the primary antibody) for Western blotting to confirm the characteristics of the six KNP proteins. As a result, catechol $O$-methyltransferase, annexin $\mathrm{V}=\mathrm{CaBP} 33$ isoform, and the unnamed protein product presented thicker bands in KNP than those in Landrace. Moreover, catechol $O$-methyltransferase was shown to be more feasible as a biomarker for KNP. However, cross-reactivity was observed with the polyclonal antibodies for KNP and the other three proteins (NADH dehydrogenase, a protein similar to T-complex protein 1, and fatty acid-binding protein). This study only showed limited results from a limited number of animals; however, our research suggests possibilities for future studies.
\end{abstract}

Key words: Korean native black pig, landrace, proteomics, longissimus dorsi muscle, polyclonal antibody, biomarker

\section{Introduction}

In the post Genomics era, proteomics studies have been the cornerstone of many important findings in meat science, commonly proteomics in meat science is focused on dissecting the molecular networks for the basis of cellular functions and physiologic processes. During post mortem, immediately after slaughter, there is a change of biochemical processes in response to the halt of the respiratory system and the circulation of blood on animal. Also in muscle cells, the ultra-structural and biochemical changes as well as the changes in energy metabolism that happened while going the post mortem have been explained (Lametsch and Bendixen, 2001). There are numerous proteomics papers in the meat science literature that analyse the genetic characteristics and/or eating quality such as meat colour, marbling, meat ageing and tenderness on various species of animals (Bendixen, 2005; Hoc-

*Corresponding author: I. H. Hwang, Department of Animal Science, Chonbuk National University, Jeonju 561-756, Korea. Tel: 82-063-270-2605, Fax: 82-063-270-2612, E-mail: inho.hwang @jbnu.ac.kr quette et al., 2009; Jia et al., 2006, 2007; Kim et al., 2008a, 2008b; Martin et al, 2007; Mastellone et al., 2011; Mullen et al., 2006; Oliveria et al., Park et al., 2009). Also several studies demonstrated metabolic proteins related with glycolysis during post mortem for early tenderness given have been being published (Jia et al., 2006, 2007).

Muscle fibre type greatly varies between pig breeds (Gariépy et al., 2001; Waritthitham et al., 2010), and that is a significant attributor to meat quality as significantly affecting pre- and post-mortal metabolic rate and/or its susceptibility to protein de-naturation (Bowker et al., 2004). The authors reported that fast MyHC iso-forms had a higher ATPase activity early post mortem than slow muscle fibres, but these were more prone to inactivation by a rapid pH decline. Kim et al. (2008a) confirmed that two genes related to energy metabolism were more highly expressed in KNP breed than Landrace pure breed. The studies, not surprising on the other hand, imply that pigs with distinctive fibre type had different expression levels of proteins. Furthermore, from the biological perspective, fibre type specific proteins might exist between two breeds with different colour and water holding capacity 
traits of the meats.

When Korean consumers buy a meat, they want to know information of the meat, and/also they prefer Korean native breeds (Jang and Kim, 2009; Lee and Jin, 2009a). Recently, several researchers presented Korean native breeds identification techniques using gene (Lee et al., 2009b; Lim et al., 2010; Yeo et al., 2000), but these technique was spent much time for identifying breed of a meat. In medical area, biomarker discovery with proteomics technique for quick diagnosis of diseases has been studied by researchers (Goo and Goodlett, 2010; Shi et al., 2009). Thus we expected that KNP specific proteins have possibility to be used biomarker for deciding whether or not KNP. Korean native black pigs (KNP) shows a slower growth rate, lighter carcass weight and more reddish meat colour than ordinary commercial pig breeds (eg, landrace crossbreed) (Park et al., 2007). The sluggish growth performance is a significant flaw from the economic standpoint, whilst the reddish meat with higher intramuscular fat content is one of the most demanded meats in Korea (Hwang et al., 2004). Park et al. (2007) recently identified four proteins (i.e., myosin regulatory light chain 2 , myosin light chain isotype $\mathrm{v} / \mathrm{sb}$, fatty acid-binding protein and albumin) which were expressed at a greatly higher level for KNP longissimus muscle than those for landrace pure-bred one.

The current study was a satellite experiment of our long term project (e.g., Park et al., 2007), and attempted to identify breed specific proteins between KNP and landrace pure-bred longissimus muscle, and raise polyclonal antibodies to validate the identified proteins from $2 \mathrm{D}$ Electrophoresis technique. The objective of this study was to find specific proteins in KNP through comparison between KNP and Landrace using proteomics technique, and suggested feasible direction to develop biomarker that can be used for industrial.

\section{Materials and Methods}

\section{Animals and sampling}

A total of six market-weighted male pigs (3 Korean native black pigs and 3 landrace pure-bred) were sampled from the previous study reported by Park et al. (2007). Pigs were transferred in approximately $3 \mathrm{~h}$ from the research station to the NIAS (National Institute of Animal Science) abattoir by the ordinary commercial trucking system, before being slaughtered the following day. Upon arrival of the animals at the abattoir, their live-weight was determined and used as the live-weight in the experimen- tal analysis. Whilst in abattoir, the animals were kept off feed, but were given free access to water. The following day animals, after a low voltage stunning (lower than $280 \mathrm{~V}$ by the mixture of head to head and head to breast technique for $2.5 \mathrm{~s}$ ), were conventionally slaughtered. During bleeding, approximately $3 \mathrm{~g}$ of tissue samples from the last rib region of longissimus muscle were taken for proteome analysis at $0 \mathrm{~h}$, and immediately placed in liquid nitrogen, then stored at $-70^{\circ} \mathrm{C}$ until analysis. After that, the carcasses were normally hung via Achilles tendon and placed in the cold storage facility at a temperature of $1^{\circ} \mathrm{C}$ until the next day. The day after slaughter, longissimus muscles were separated, and muscle samples were vacuum packed and then aged for $7 \mathrm{~d}$ at a $4^{\circ} \mathrm{C}$ for proteome analysis at day 7 . Also all of muscle tissue kept at $-70^{\circ} \mathrm{C}$ were powdered in liquid nitrogen using mortarbased homogenizer (Warning, Dynamics Corp., USA) for a gel based proteomics analysis, and stored at $-70^{\circ} \mathrm{C}$ until used.

\section{Proteome analysis}

For 2DE analysis, $50 \mathrm{mg}$ muscle sample was homogenized with $1 \mathrm{ml}$ whole extraction buffer containing $7 \mathrm{M}$ urea, $2 \mathrm{M}$ thiourea, 2\% CHAPS, 1\% DTT, $40 \mu \mathrm{L}$ Protease Inhibitor Cocktail (Roche, Germany) and 0.8\% IPG buffer $\mathrm{pH}$ range 4-7 using handheld sample grinding kit (GE health care, USA). Then grinded sample was sonicated at $10^{\circ} \mathrm{C}$ for $10 \mathrm{~min}$ and incubated at $25^{\circ} \mathrm{C}$ for 20 min, and then sample solution was centrifuged at 40,000 $\mathrm{g}$ at $15^{\circ} \mathrm{C}$ for $1 \mathrm{~h}$. The supernatant fraction of each sample was taken, and the protein concentration was determined using 2D-Quant Kit (Ettan Dalt, GE Healthcare, USA). The samples extracted were separated by a 2DE system (GE healthcare, USA), largely according to the method described by Yan et al. (2001) and Hwang et al. (2005). Gels were stained by $0.1 \%$ colloidial coomassie briliant blue G-250 in 2\% phosphoric acid, 10\% ammonium sulphate, and 20\% methanol for $48 \mathrm{~h}$ (Westermeier and Naven, 2002), and were digitalized by an imaging system (Versadoc Model 3000, Bio-Rad, USA). Triplicate gels for each sample were analysed using 2DE image analysis software (PD-Quest, Bio-Rad, USA) according to the manufacturer's instruction. Targeted spots were excised using an automated spot cutter (Proteome Works, BioRad, USA) by a circular plug of $1.5 \mathrm{~mm}$ in diameter, and transferred to polypropylene 96 well reaction plates. Proteins were subjected to in-gel trypsin digestion (Yan et al., 2001). MALDI-MS spectra were obtained using a delayedextraction reflection time-of-flight mass spectrometer 
(Model MALDI-R, Micromass, UK), while MS/MS spectra were generated by nano-ESI on a Q-TOF2 mass spectrometer (Micromass). The data were processed using a Mass Lynx Windows NT PC system. Peptide masses from MALDI-TOF MS were matched with the theoretical peptides of proteins in the NCBI database using MASCOT and/or Profound software. Also, all MS/ MS spectra recorded on tryptic peptides were searched against protein sequences from NCBI and EST databases using the MASCOT search program (www.matrixscience. com).

\section{Rising polyclonal antibodies}

Six proteins (all of proteins were observed on only KNP, also 3 proteins among them were decreased or increased during ageing; similar to NADH dehydrogenase, unnamed protein product, similar to T-complex protein 1, annexin $\mathrm{V}=\mathrm{CaBP} 33$ isoform, fatty acid-binding protein, Catechol $O$-methyltransferase) differently expressed proteins between KNP and Landrace, were selected and rose polyclonal antibodies that were processed from rabbits. The domains of polyclonal antibodies were chosen based on both low hydrophobicity and high antigenicity exist because they demonstrated high capability to be made specific antibody also had high probability to be exposed the outside of three dimensional protein structure of the specific proteins. Consequently, these polyclonal antibodies were rose using regions near N-term and/or C-term of hydrophobicity and antigenicity in whole protein.

\section{Western blotting}

Each muscle samples, which were previously used for proteome analysis stored at $-70^{\circ} \mathrm{C}$ until analysis, were homogenised in extract buffer containing $50 \mathrm{mM}$ Tris and 10 mM EDTA, pH 8.3 for 20 s, 3 times. protein concentration were determined by using protein assay kit (BIORAD, USA) and made up to $2 \mathrm{mg} / \mathrm{mL}$ protein concentration with treatment buffer which contained $0.125 \mathrm{M}$ Tris, $4 \%$ SDS, $20 \%$ glycerol, $0.1 \%$ MCE, $1 \%$ bromophenol blue. This is boiled for $5 \mathrm{~min}$, and then kept at room temperature overnight. The immunoblotting was principally conducted according to the method of Hwang et al. (2004) with following modification. Ten microliters of the sample was separated at $130 \mathrm{~V}$ for $60 \mathrm{~min}$. using acrylamide gel ( $4 \%$ stocking and $12 \%$ resolving gel), and transferred to $0.2 \mu \mathrm{m}$ PVDF membrane (BIO-RAD, USA) at $200 \mathrm{~mA}$ for $120 \mathrm{~min}$ in transfer buffer (10\% Methanol, $192 \mathrm{mM}$ glycine, $25 \mathrm{mM}$ Tris). After transfer, membrane was blocked using 5\% skim milk-TTBS (5\% skimmed mink in TTBS contained $20 \mathrm{mM}$ Tris, $137 \mathrm{mM} \mathrm{NaCl}, 5$ $\mathrm{mM} \mathrm{KCl}, 0.05 \%$ Tween 20 ) at room temperature for $1 \mathrm{~h}$. Blots were incubated with each primary antibodies, which were polyclonal antibodies that were made using the 6 proteins, diluted 1:1,000 in TTBS for 60 min under the same conditions. The bound primary antibodies were then labelled (60 $\mathrm{min}$ at room temperature) with goat anti-rabbit IgG HRP conjugated secondary antibody (Sigma, USA) diluted 1:2,500 in TTBS. The bound antibodies were visualized by incubating membranes with BCIP/NBT substrate (BIO-RAD) according to the manufacturer's guide. Images were taken by Floure-S (BIORAD).

\section{Results and Discussion}

Korean native black pig has been widely grown until 1970's in Korea, but at the time there was no implementation for improving breeds for lean meat production and fast growth, consequently a number of KNP growing was significantly recessed. However, when comparing KNP with commercial pig breeds, such as cross-breed and Landrace, there is not enough genetic information related to meat quality traits. Phenotypically, the meat of KNP shows reddish and has high intracellular fat content. This is more desirable by most of Korean consumers (Hwang et al., 2004).

In our previous study (Park et al., 2007), which this study followed to, showed that KNP had a significantly $(p<0.05)$ higher content of myosin heavy chain1, and concurred with greatly $(p<0.05)$ with higher inter muscular fat content and Hunter $a^{*}$ value, and significantly $(p<0.05)$ lower drip loss than those seen in Landrace. In addition, the result of proteomics analysis reported that approximately a hundred proteins were found in abundance while store ( $0 \mathrm{~h}$ and $7 \mathrm{~d}$ ) on various breed of KNP and Landrace, in which 26 proteins were changed more than threefold to be related ageing. Jia et al. (2007) reported that the expression levels most affect during the $24 \mathrm{~h}$ post slaughter are those of HSP and the energy and protein metabolism enzyme using proteomics analysis. Similarly we observed mainly cellular defence/stress proteins and energy/protein metabolism enzymes in the group increased during aging. In this regard, 12 protein spots were increased in density more than threefold including three structural proteins (actin, myozenin 1 and f-actin capping protein $\beta$ ), four energy and protein metabolic enzymes (adenylate kinase, dehydrogenase oxidase, GDPH and cytochrome c oxidase subunit) and five cellu- 
lar defence/stress proteins (alpha B-crystallin, f-box/WDrepeat protein $1 \mathrm{~A}$, heat shock cognate 71 , heat shock protein 27 and heat shock protein 70.2) during ageing period. On the other hands, 14 protein spots decreased in density while the intensities of 12 proteins increased, these were mainly structural proteins and plasma proteins. In the study, especially, there were five noteworthy protein, which were myosin regulatory light chain 2 , myosin light chain isotype $\mathrm{v} / \mathrm{sb}$, fatty acid-binding protein and albumin, that were greatly higher in density for KNP at $0 \mathrm{~h}$ sample (Park et al, 2007).

For the rising antibody of KNP specific protein (Table 1 ), the proteins that were differed in density compared and sorted by ageing between KNP and Landrace, there were six proteins in only KNP muscle, also three proteins (NADH dehydrogenase Fe-S protein 1, Unnamed protein product, Similar to T-complex protein 1) among them were observed during ageing, and the other three proteins (Annexin $\mathrm{V}=\mathrm{CaBP} 33$ isoform, Fatty acid-binding protein, Catechol O-methyltransferase) disappeared with ageing status.

For two proteins existed during ageing in only KNP muscle, NADH dehydrogenase Fe-S protein (NADHS1) and T-complex protein 1 (TPC-1-epsilonis) are associated with ATP metabolism, NADHS1 is located at the mitochondrial inner membrane and related ATP synthesis, it transfers electrons from NADH to the respiratory chain, and TCP-1-epsilonis not only assist of proteins upon ATP hydrolysis and chaperon and folding catalysts at cytoplasm, but also is essential in the folding of actin and tubulin (Grigorieff, 1999; Kubota et al., 1995; Yokota et al., 2000). These two proteins related energy metabolism expressed only in KNP muscle is due to glycolysis progressing speed in red muscle including KNP (Kim et al., 2008a; Park et al., 2007). On the other hand, on the other five proteins included two structural proteins disappeared with ageing. Annexin $\mathrm{V}=\mathrm{CaBP} 33$ isoform has been par- ticipated to $\mathrm{Ca}$ ion channel activities. This protein's biological roles are not known, but reported to be widely distributed in animal tissue by immunology (Giammbanco et al., 1993). Fatty acid binding protein plays a role in lipid-metabolism, and controls cell proliferation in muscle and heart, it activates PPAR signalling pathway, also Grebens et al. (1999) suggested feasible that this protein can be used to biomarker for increasing intramuscular fat in pig muscle. Catechol $O$-methyltransferase (COMT) is a ubiquitous enzyme that is involved in the inactivation of catecholamine, it works controlling on automatic nervous system and inhibition of degradation fat on muscle cells through steroid biosynthesis, thyrosin metabolism and beta actin metabolism pathway (Annerbrink et al. 2008; Niehaus et al. 2001).

Finally polyclonal antibodies for six proteins (NADH dehydrogenase $\mathrm{Fe}-\mathrm{S}$ protein 1 isoform, unnamed protein product, Similar to T-complex protein 1, Annexin $\mathrm{V}=$ $\mathrm{CaBP} 33$ isoform, fatty acid-binding protein, Catechol $O$ methyltransferase) were rose using rabbits for verifying specific protein in KNP and Landrace (Table 1 and Fig. 1). In Fig 2, there were thicker bands at the polyclonal antibody blot 1 (Catechol O-methyltransferase), blot 2 (annexin $\mathrm{V}=\mathrm{CaBP} 33$ isoform) and blot 4 (unnamed protein product) in KNP than Landrace, particularly the case of polyclonal antibody 1 appeared to specific band in only KNP, and it presents theoretical feasibility to use for indicating KNP at industrial area. Nevertheless, at the other polyclonal antibodies which were rose using NADH dehydrogenase, similar to T-complex protein 1 and fatty acid-binding protein, there were not shown specific band for KNP, and we expected that a traits of polyclonal antibody involved a lot of their non-specific binding in both breeds. Thus the results of this study leave more research to be required with raising monoclonal antibodies for these specific proteins. To be sure, this study begins with the limited results from a limited number of animals

Table 1. List of proteins and changes in spot density in arbitrary unit for Landrace (Lan) and Korean native black pig (KNP) immediately after slaughter $(0 \mathrm{~h})$ and $7 \mathrm{~d}$ storage at $4^{\circ} \mathrm{C}$

\begin{tabular}{|c|c|c|c|c|c|c|c|c|}
\hline \multirow{2}{*}{ Spot no. } & \multirow{2}{*}{ Identified fragments } & \multirow{2}{*}{$\begin{array}{l}\text { NCBI Access } \\
\text { number }\end{array}$} & \multirow{2}{*}{$\mathrm{C} / \mathrm{Q}^{\dagger \mathrm{y}}$} & \multirow{2}{*}{$\begin{array}{l}\text { Estimated } \\
\mathrm{MW} / \mathrm{pI}\end{array}$} & \multicolumn{4}{|c|}{ Spot density } \\
\hline & & & & & Lan $0 \mathrm{~h}$ & Lan $7 \mathrm{~d}$ & KNP $0 \mathrm{~h}$ & KNP $7 \mathrm{~d}$ \\
\hline 3904 & $\begin{array}{l}\text { NADH dehydrogenase Fe-S protein } 1 \text {, } \\
75 \mathrm{kDa} \text { precursor isoform } 3\end{array}$ & gi|74005204 & $23 / 15$ & $80717 / 6.04$ & 0 & 0 & 4.98 & 2.45 \\
\hline 4805 & Unnamed protein product & gi|1335218 & $13 / 9$ & $102241 / 5.23$ & 0 & 0 & 4.33 & 6.04 \\
\hline 5801 & Similar to T-complex protein 1 & gi|74003009 & $23 / 16$ & $60055 / 5.58$ & 0 & 0 & 24.60 & 11.20 \\
\hline 1305 & Annexin $\mathrm{V}=\mathrm{CaBP} 33$ isoform & gi|260137 & $32 / 7$ & $35978 / 4.94$ & 0 & 0 & 9.32 & 0 \\
\hline 2119 & Fatty acid-binding protein & gi|2143386 & $26 / 5$ & $14797 / 6.11$ & 0 & 0 & 11.24 & 0 \\
\hline 2215 & Catechol O-methyltransferase & gi|544074 & Q-ToF & $20859 / 6.1$ & 0 & 0 & 18.59 & 0 \\
\hline
\end{tabular}

${ }^{\mathrm{C}} \mathrm{C} / \mathrm{Q}$, Percentage of coverage/number of matched query for MALDI-TOF analysis; ${ }^{\mathrm{y}}$ Peptide sequence for Q-ToF analysis, Q-ToF 1 

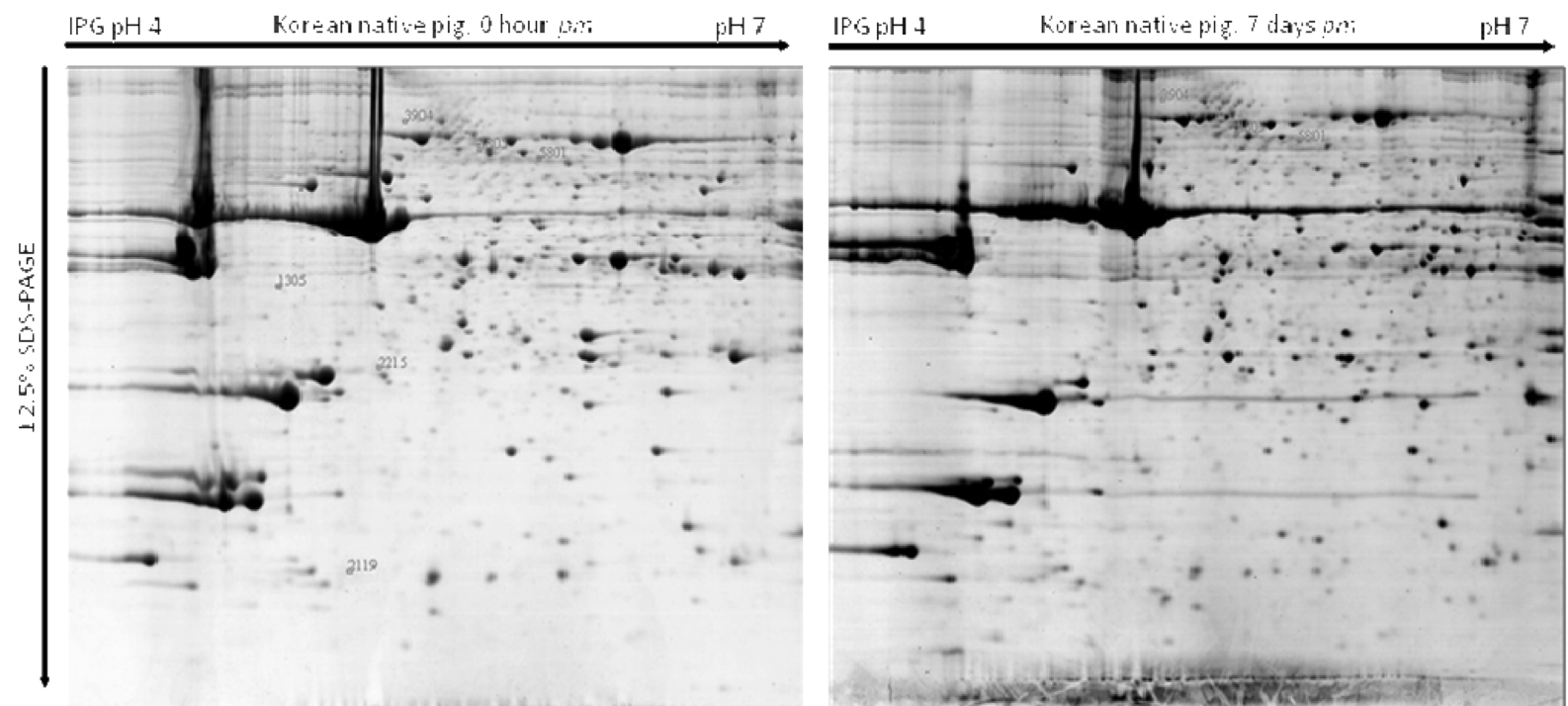

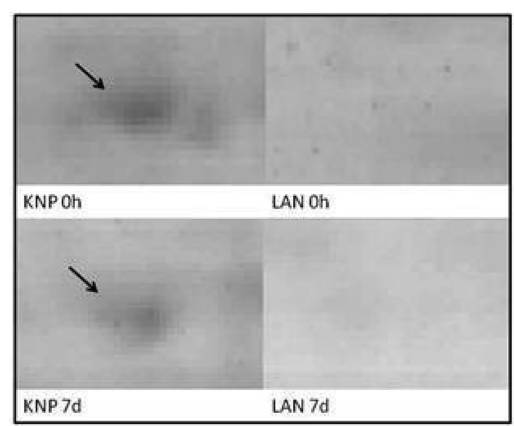

Spot 3904

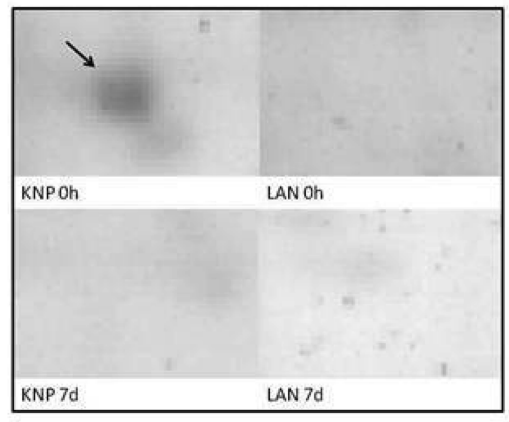

Spot 1305

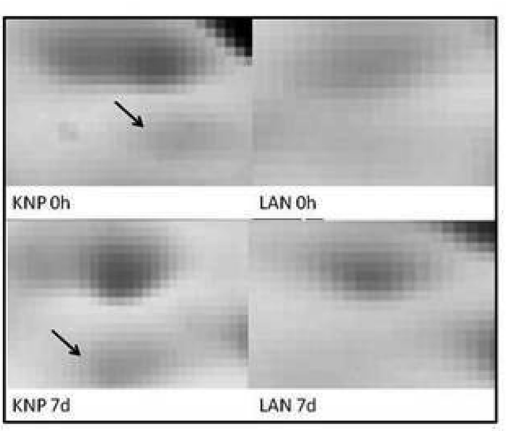

Spot $\mathbf{4 8 0 5}$

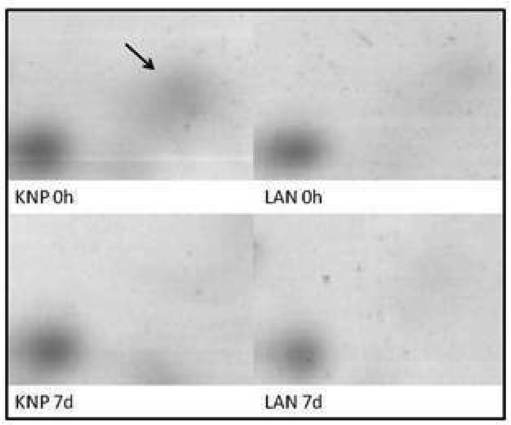

Spot 2119

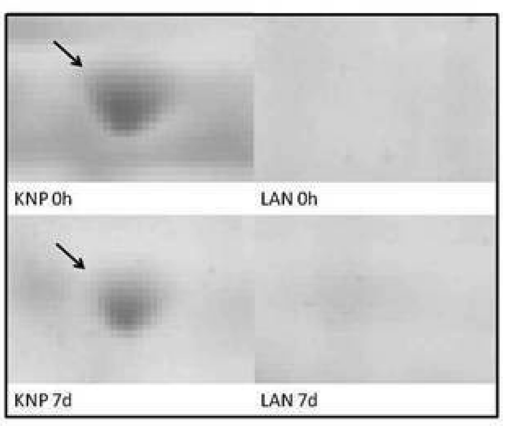

Spot 5801

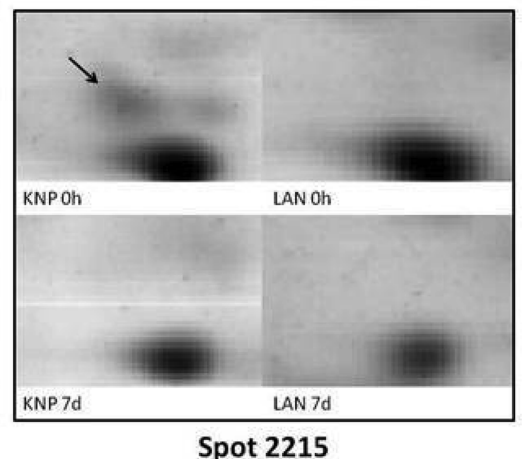

Fig 1. Representative 2DE electrophoresis profile and spots number of specific proteins of Korean native black pig (KNP) at $0 \mathrm{~h}$ and $7 \mathrm{~d}$. The three proteins, (NADH dehydrogenase Fe-S protein 1,75kDa precursor isoform 3, spot no. 3094; Unnamed protein product, spot no. 4805; Similar to T-complex protein 1, spot no. 5801) were increased and/or decreased, and another three proteins ( Annexin V=CaBP33 isoform, spot no. 1305; Fatty acid-binding protein, spot no. 2119; Catechol $O$-methyltransferase, spot no. 2215) were disappeared during ageing.

involved that was not found and made obvious indicator proteins/antibodies for KNP. Although it has good reason to report it, as we believe this results can become a case to be considered for future researches.

In the previous study (Park et al., 2007), we found six proteins (NADH dehydrogenase Fe-S protein 1, Unnamed protein product, Similar to T-complex protein 1Annexin $\mathrm{V}=\mathrm{CaBP} 33$ isoform, Fatty acid-binding protein, Catechol $O$-methyltransferase) appeared in KNP merely, and rose polyclonal antibodies (used to primary) for western blotting to confirm specification of six protein with KNP. In result, Catechol $O$-methyltransferase, Annexin $\mathrm{V}=\mathrm{CaBP} 33$ isoform, Unnamed protein product were presented thicker band in KNP than Landrace, moreover Catechol $O$-methyltransferase was shown feasibility to be used biomarker for KNP. However there were not specification of KNP with the other three proteins, which were NADH dehydrogenase, similar to T-complex protein 1 and fatty acid- 


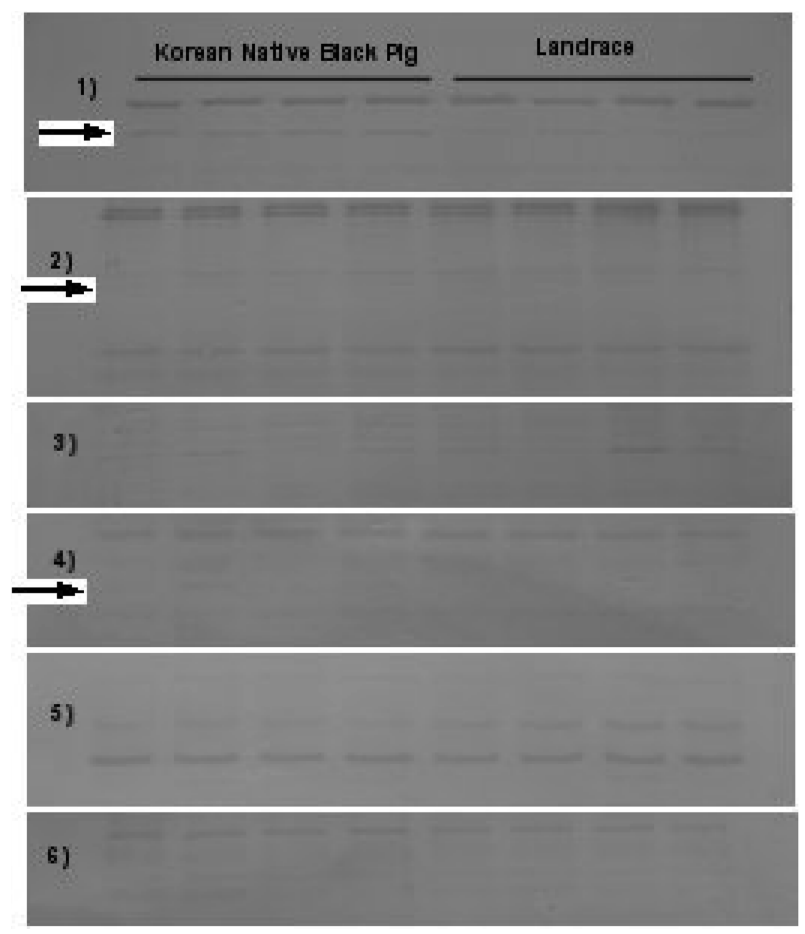

Fig 2. Western blotting of poly-colonel antibodies raised against rabbit for longissimus muscles of Korean native black pig (left 4 lanes) and landrace (right 4 lanes). Protein names for raising antibodies were Catechol $O$-methyltransferase (1), annexin $\mathrm{V}=\mathrm{CaBP} 33$ isoform (2), fatty acid-binding protein (3), unnamed protein product (4), similar to T-complex protein 1 (5) and similar to NADH dehydrogenase (6). Arrows for blots 1), 2), and 4) indicate a particular band appeared more extensively for Korean native black pig. Particularly band for blot 1) was mostly noticeable.

binding protein. Although this study remained more research to be needed with the limited current results and number of animals, the current study demonstrated a possibility that can become a case to be considered for future researches

\section{Acknowledgement}

This work was supported by a co-grant from both the BioGreen 21 program and Next-Generation BioGreen 21 Program, Rural Development Administration, Republic of Korea (NO.PJ008191).

\section{References}

1. Annerbrink, K., Westberg, L. Nilwwon, S., Rosmond, R, Holm, G., and Eriksson, E. (2008) Catechol O-methyltransferase val158-met polymorphism is associated with abdominal obesity and blood pressure in men. Metabolism 7, 708-
711.

2. Bendixen, E. (2005) The use of proteomics in meat science. Meat sci. 71, 138-149.

3. Bowker, B. C., Botrel, C., Swartz, D. R., Grant, A. L., and Gerrard, D. E. (2004) Influence of myosin heavy chain isoform expression and postmortem metabolism on the ATPase activity of muscle fibers. Meat Sci. 68, 587-594.

4. Gariépy, C., Farmer, C., Lamontagne, N., Manzalini, L., and Faucitano, L. (2001) A comparative study on muscle fibers and meat quality from Large White and Upton-Meishan pigs. Proceed. 47th Int. Cong. Meat Sci. Technol., Krakow, Poland, pp. 262-263.

5. Gerbens, F., van Erp, A. J., Harders, F. L., Verburg, F. J., Meuwissen, T. H., Veerkamp, J. H., and te Pas, M. F. (1999) Effect of genetic variats of the heart fatty acid-binding protein gene on interamuscular fat and performance traits in pig. J. Anim. Sci. 77, 846-852.

6. Giammbanco, I., Sorci. G., Antonioli, S., Rambotti, M. G., Spreca, A., Bocchini, V., and Donato, R. (1993) Immunocytochemmical analysis of annexin $\mathrm{V}(\mathrm{CaBP} 33)$ in a humanderived giloma cell line. FEBS 323, 45-50.

7. Goo, Y. A. and Goodlett, D. R. (2010) Advances in proteomics prostate cancer biomarker discovery. Proteomics 73, 1839-1850.

8. Grigorieff, N. (1999) Structure of the respiratory NADH: ubiquinone oxidoreductase (complex I). Curr. Opin. Struct. Biol. 9, 476-484.

9. Hocquette, J. F., Isabell, C. M., Carine B. C., and Brigitte P. (2009) Functional genomics and now markers for beef production-minireview. Anim. Sci. Pap. Rep. 27, 273-280.

10. Hwang, I. H., Park, B.Y., Cho, S. H., Kim, J.H., and Lee, J. M. (2004) Identification of muscle proteins related to objective meat quality in Korean native black pig. Asian Austral. J. Anim.17, 1599-1607.

11. Hwang, I. H., B. Y. Park, J. H. Kim, S. H. Cho and J. M. Lee. (2005) Assessment of postmortem proteolysis by gel-based proteome analysis and its relation to meat quality traits in pig longissimus. Meat Sci. 69, 79-91.

12. Jia, X. H., Hildrum, K. I., Westad, F., Kummen, E., Aass, L., and Hollung K. (2006) Change in enzyme associated with energy metablism during the early post mortem period in longissimus thoracis bovine muscle analyzed by proteomics. J. Proteome Res. 5, 1763-1769.

13. Jang, K.Y. and Kim, H. (2009) Purchasing situations of beef and the level of consumer's satisfaction on Australian beef. Korean Soci. Intl. Agri. 21, 85-90.

14. Jia, X. H., Ekman, M., Grove, H., Faergestad, E. M., Aass, L., Hildrum, K. I. and Hollung, K. (2007) Proteomics change in bovine longissimus thoracis muscle during the early postmortem storage period. J. Proteome Res. 6, 2720-2731.

15. Kim, N. K., Lim, J. H., Song, M. J., Kim, O. H., Park. B. Y., Kim, M. J., Hwang, I. H., and Lee, C. S. (2008a) Comparisons of longissimus muscle metabolic enzymes and muscle fiber types in Korean and western pig breeds. Meat Sci. 78, 455-460.

16. Kim, N. K., Cho, S. H., Lee, S. H., Park, H. R., Lee, C. S., 
Cho, Y. M. Choy, Y. H., Yoon, D. Im, S. K., and Park, E. W. (2008b) Protein in longissimus muscle of Korean native cattle and their relationship to meat quality. Meat Sci. 80, 10681073.

17. Kubota, H., Hynes, G., and Willison, K. (1995) The chaperonin containing t-complex polypeptide 1 (TCP-1). Multisubunit machinery assisting in protein folding and assembly in the eukaryotic cytosol. Eur. J. Biochem. 230, 3-16.

18. Lametsch, R. and Bendixen, E. (2001) Proteome analysis applied to meat science: Characterizing postmortem changes in porcine muscle. J. Agr. Food Chem. 49, 4531-4537.

19. Lee, K. Y. and Kim, H. (2009) Purchasing situation of beef and the level of consumer's satisfaction on Australian beef. Korean J. Intl. Agri. 21, 85-90.

20. Lee, S. M. and Jin, Y. H. (2009a) Research on consumer awareness due to origin declaration of beef in general restaurant. Korean J. Cul. Res. 15, 112-127.

21. Lee, S. M., Lee, W. W., Lee, G. R., and Lee, D. S. (2009b) Differentiation of Hanwoo and other breeds of cattle using PCR-PFLP and Allele-specific PCR. Ann. Rep. Busan Metro. City Inst. Health Environ. 19, 88-93.

22. Lim, D., Cho, Y. M., Lee, S. H., Sung, S., Nan, J., Yoon, D., Shin, Y., Park, H., and Kim, H. (2010) An integrated genomic resource based on Korean Cattle (Hanwoo) transcripts. Asian-Aust. J. Anim. Sci. 23, 1399-1404.

23. Martin, I., Garcia, T., Fajardo, V., pez-Calleja, I. L., Rojas, M., Hemandez, P. E., Gonza, I., and Martin, R. (2007) Mitochondrial markers for the detection of four duck species and the specific identification of Muscovy duck in meat mixtures using the polymerase chain reaction. Meat Sci. 76, 721-729.

24. Mastellone, V., Massimini, G., Pero, M. E., Cortese, L., Piantedosi, D., Lombardi, P., Britti, D., and Avallone, L. (2011) Effect of passive transfer status on growth performance in Buffalo calves. Asian-Aust. J. Anim. Sci. 24, 952956.

25. Mullen, A. A. M., Stapleton, P. C., Corcoran, D., Hamill, R. M., and White, A. (2006) Understanding meat quality through the application of genomic and proteomics approaches. Meat Sci. 74, 3-16.

26. Niehaus, D. J. H., Kinnear, C. J., Corfield, V. A., Toit, P. L., Kradenburg, J. Moolman-Smook, J. C., Weyer, J. B., Potgieter, A., Seedat, S. Emsley, R. A., Knowles, J. A., Brink, P. A., and Stein, D. J. (2001) Association between a catechol-omethyltransferase polymorphism and obsessive-compulsive disorder in the Afrikaner population. J. Affect. Disorders 65, 61-65.

27. Oliveira, G. C., Moreira, I., Souza, A. L. P., Murakami, A. E., Parra, A. R. P., Carvalho, P. L. O., and Borile, M. D. (2011) Corns with different nutritional profiles on growing and finishing pig feeding (30 to $90 \mathrm{~kg}$ ). Asian-Aust. J. Anim. Sci. 24, 982-992.

28. Park, B. Y., Kim, N. K., Lee, C. S., and Hwang, I. H. (2007) Effect of fiber type on postmortem proteolysis in longissimus muscle of Landrace and Korean native black pigs. Meat Sci. 77, 482-491.

29. Park, J. K., Lee, J. Y., Chea, B. H. J., and Ohh, S. J. (2009) Effect of different sources of dietary chromium on growth, blood profiles and carcass traits in growing-finishing pig. Asian-Aust. J. Anim. Sci. 22, 1547-1554.

30. Pennington, S. R. and Dunn, M. J. (2001) Proteomics from protein sequence to function. Springer-Verlag, New York, USA.

31. Shi, M., MCaudle, M. W., and Zhang, J. (2009) Biomarker discovery in neurodegenerative diseases: A proteomic approach. Neurobiol. Dis. 35, 157-164.

32. Waritthitham, A., Lambertz, C., Langholz, H. J., Wicke, M., and Gauly, M. (2010) Muscle fiber characteristics and their relationship to water holding capacity of Longissimus dorsi muscle in Brahman and Charolais crossbred bulls. AsianAust. J. Anim. Sci. 23, 665-671.

33. Westermeier, R. and Naven, T. (2002) Proteomics in practical-A laboratory manual of proteomics analysis. Wiley-Vch, Freibury, Germany.

34. Yan, J. X., Harry, R. A., Wait, R., Welson, S. Y., Emery, P. W., Preedy, V. R., and Dunn, M. J. (2001) Separation and identification of rate skeletal muscle proteins using twodimensional gel electrophoresis and mass spectrometry. Proteomics 1, 424-434.

35. Yeo, J. S., Lee, J. S., Lee, C. H., Jung, Y. J., and Nam, D. H. (2000) Identification of genetic markers for Korean native cattle (Hanwoo) by RAPD analysis. Biotechnol. Bioprocess Eng. 5, 23-26.

36. Yokota, S. I., Yanagi, H. Yura, T., and Kubota, H. (2000) Upregulation of cytosolic chaperonin CCT subunits during recovery from chemical stress that causes accumulation of unfolded proteins. Eur. J. Biochem. 267, 1658-1664.

(Received 2011.4.29/Revised 1st 2011.7.7, 2nd 2011.7.10/ Accepted 2011.7.11) 